McKim of Melville who sent in an ineresting page of bird notes from the cal area. He was also cited for his ribute to Judge J. M. Patrick of Moosomin (formerly of Yorkton) who ied suddenly on June 9. "He was a rue conservationist", wrote Judge McKim in the Yorkton Enterprise, even before many of us realized the ecessity of protecting our game birds nd animals and contributed in no mall way to bringing into effect many heasures for their preservation." For ver 25 years Judge Patrick had mainained a deer park and bird sanctuáry $n$ the outskirts of Yorkton, until he hoved to Moosomin in 1935.

In this issue the Blue Jay also paid ribute to other publications featuring lature columns. Marion Nixon's
"Nature" in the Saskatchewan Farmer had been mentioned in the previous issue, and now members were also urged to read Mrs. Elizabeth Flock's delightful nature articles that appeared from time to time in the Regina Leader-Post. Another nature column was being conducted in the young people's section of the Western Producer under the heading "Do You Watch the Birds?" In this column letters were printed from "voung cooperators" describing the birds they had seen and fed. "Do You Watch the Birds?" had been running for some years and Mrs. Priestly commended the column on doing good work in encouraging the younger generation to take an interest in the bird life of the province.

\title{
ANNUAL MEETING SASKATCHEWAN NATURAL HISTORY SOCIETY
}

The 25th Annual Meeting will be held in Saskatoon at the Saskatchewan Institute of Applied Arts and Sciences, Idylwyld Drive and 33rd Street, commencing Friday evening October 12 th and continuing all day Saturday. In addition to the business sessions, there will be natural history programs and the annual supper - an opportunity to participate in Society affairs and help chart its future, and to pursue natural history interests among friends.

The Honourable Jean Chretien, Minister of Indian Affairs and Northern Development, whose ministry includes national parks, has been invited to be our guest speaker.

Following are names and addresses of the chairmen of the key committees. If you have any suggestions please get in touch with them.

- Resolutions, Tom Gentles, 41 Langley St., Regina.

If possible, send proposed resolutions to Tom by October 10 th.

- Nominations, Frank Roy, 1702 Sommerfeld Ave., Saskatoon.

- Awards, Dr. Stuart Houston, 863 University Dr., Saskatoon.

- Annual Meeting Arrangements, Mrs. J. W. Gerrard, 809 Colony St., Saskatoon.

All members are urged to attend. On this, the occasion of the 25th Annual Meeting, a special invitation is extended to members who joined the Society in its initial year.

Further details will appear in the next issue of the Newsletter. 